\title{
Impact of Wind Farms on the Economic and Financial Standing of the Korsze Commune
}

\author{
Izabela Rogalska*, Damian Opalach**, Radostaw Sańko****
}

Being an inexhaustible source of ecologically pure energy, wind is gaining an increasingly wider range of applications. This translates into the growing interest of investors in areas endowed with the conditions suitable for developing wind farms. An investment into wind turbines can generate many economic benefits for a local government, chiefly by ensuring higher revenues from real estate taxes. The main objective of this study has been to evaluate the impact of wind farms on the economic and financial standing of the Korsze commune. The study included secondary data obtained from the Municipal Office in Korsze and statistical data from Statistics Poland. The results showed that the implementation of the investment project consisting of building a wind farm in Korsze led to the commune acquiring new and stable sources of revenue, with distinctly higher real property tax incomes. Annually, the real estate tax revenues in Korsze in the first year after the wind farm had opened increased by $48 \%$.

Keywords: renewable energy sources, wind farms, local government, municipal budget.

Submitted: 04.03.2020 | Accepted: 17.06.2020

\section{Wpływ elektrowni wiatrowych na sytuację ekonomiczną gminy miejsko-wiejskiej}

Wiatr jako niewyczerpywalne źródto czystej ekologicznie energii znajduje coraz szersze zastosowanie i cieszy się coraz większym poparciem społecznym. Przektada się to na duże zainteresowanie ze strony inwestorów $w$ gminach posiadających odpowiednie warunki do budowy farm wiatrowych. Inwestycje w farmy wiatrowe przynosza wiele korzyści ekonomicznych samorzadom lokalnym, m.in. zwiększając ich dochody pochodzace w gtównej mierze z podatku od nieruchomości. Gtównym celem przeprowadzonych badań byta ocena wptywu elektrowni wiatrowych na sytuacje ekonomiczna gminy Korsze. Do badań wykorzystano dane wtórne pozyskane z materiatów źódłowych zgromadzonych przez dziaty informacyjne Urzędu Miejskiego w Korszach oraz ze statystyki Gtównego Urzędu Statystycznego. Otrzymane wyniki badań wykazaty, że zrealizowanie inwestycji zwiazanej z budowa farmy wiatrowej $w$ Korszach wptynęto na uzyskanie nowych, stabilnych źródet dochodów i znacznie zwiększyło dochody

\footnotetext{
* Izabela Rogalska - MA, Department of Economic Policy, University of Warmia and Mazury in Olsztyn, Poland, https://orcid.org/0000-0002-2614-5967.

** Damian Opalach - MA, Department of Economic Policy, University of Warmia and Mazury in Olsztyn, Poland, https://orcid.org/0000-0002-4484-3419.

**** Radosław Sańko - BA, Department of Economic Policy, University of Warmia and Mazury in Olsztyn, Poland.

Correspondence address: Department of Economic Policy, University of Warmia and Mazury in Olsztyn, ul. Oczapowskiego 4/13, 10-719 Olsztyn, Poland; e-mails: izabela.serocka@uwm.edu.pl; damian.opalach@uwm.edu.pl; radoslaw.sanko@student.uwm.edu.pl
} 
z tytutu podatku od nieruchomości. Roczne wptywy z tytutu tego podatku już w pierwszym roku funkcjonowania farmy wiatrowej wzrosty o $48 \%$.

Słowa kluczowe: odnawialne źródła energii, elektrownie wiatrowe, samorząd lokalny, budżet gminy.

Nadesłany: 04.03.2020 | Zaakceptowany do druku: 17.06.2020

JEL: H70, Q28, Q42, O13

\section{Introduction}

The use of renewable energy sources (RES) in the economies of individual countries is closely related to the sustainable development implementation. Poland as a member of the European Union in accordance with the Europe 2020 Strategy or the 2030 Agenda, as well as upcoming strategies such as Sustainable Europe by 2030, should lead to a high level of socioeconomic development, but respecting the principles of sustainable development (Strategia na rzecz..., 2017). Additionally, it was emphasised in the presented sectoral strategic documents, inter alia The Energy Policy of Poland until 2040 (EPP2040) (Marks-Bielska et al., 2020). The use of renewable energy sources can be counted as a component of sustainable development that combines measurable energy outcomes and ecological effects. The increasing use of RES in the world helps to save energy resources, improve the condition of the natural environment and sustain the economic growth (Apergis \& Payne, 2010; Menyah \& Wolde-Rufael, 2010; Payne, 2010; Gozgor, 2016).

Poland's entry into the global trend of using RES requires an appropriate financial outlays - especially in less developed regions, of which there is no shortage in Poland (e.g. Eastern Poland). Fortunately, legal regulations based on the above-mentioned strategies, stipulate various forms of co-financing, offered to parties interested in making changes in power generation and consumption (Carvalho, 2012; Kim \& Wilson, 2019). Therefore, in recent years, the role of renewable energy sources in Poland has gained momentum as well, especially when RES enable power generation in poorly industrialised areas, distant from agglomerations and lacking fossil fuels (Żygadło \& Madejski, 2016).
Additionally, local authorities are increasingly willing to join programmes aiming to develop renewable energy resources (Jabłońska \& Zieliński, 2011; Marks-Bielska \& Bielski, 2013; 2018; Marks-Bielska et al., 2019).

One of the types of RES are wind farms, and their expansion and development in Poland has been noticeable since 2001, i.e. from the establishment of the first wind farm in the country. The impact of wind farms on socio-economic development was the subject of research studies, including in Asia, Europe or Poland. Based on the available research results, the positive importance of wind energy in this process should be noted, for example in Poland (Igliński et al., 2016), Scotland (Munday et al., 2011), Germany, Great Britain (Nolden, 2013), Spain (Copena et al., 2019) or Jordan (Hilpert et al., 2020). Undoubtedly, the dynamic increase in the importance of wind energy in recent years contributes to the situation in which the research must be continued taking into account many socioeconomic factors.

Therefore, the purpose of this article was to assess the impact of wind farms on the socio-economic situation at the local level in the Korsze commune in Warmia and Mazury province. The research used the observational method and the method of examining documents.

The key idea of sustainable development is intergenerational justice, which consists in providing all generations with equal access to the resources of the natural, social and economic environment. The research problem undertaken in the study is important because, on the one hand, it fits closely with the sustainable development concepts, and on the other hand, it shows that the use of renewable energy sources gives development opportunities to less developed communes. 


\section{Changes in Taxes Levied on Wind Farms Due to Different Definitions of the Building Object}

Since the early $21^{\text {st }}$ century, the wind power generation has been growing at a rate of $20-30 \%$ a year. The total power of wind farms built until 2000 was 18 $\mathrm{GW}$, rising to $434 \mathrm{GW}$ in 2015. In 2015, wind farms supplied the global population with 841 TWh, which was $3.5 \%$ of the world's demand for electric power (BP, 2016).

Since 2010, wind energy has been one of the largest branches of electricity based on renewable energy sources in Poland. At the end of 2019, the capacity of wind farms installed in Poland was 5.92 GW, which accounted for $64.98 \%$ of the total RES capacity in the country (Figure 1). Compared to 2010, this meant an increase by as much as $401 \%(4.74 \mathrm{GW})^{1}$.

Figure 1. Renewable energy sources of electricity in Poland in 2019

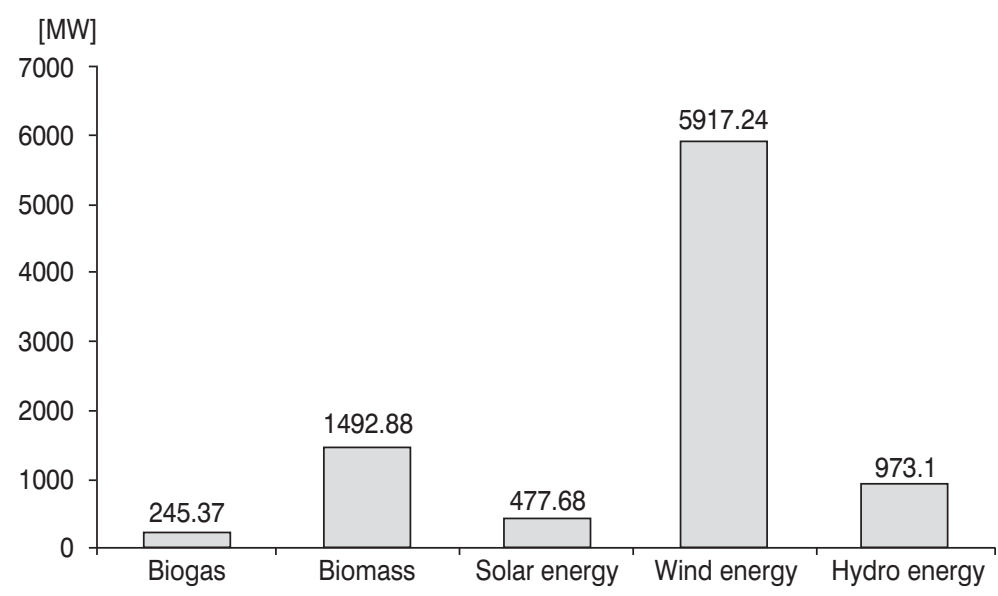

Source: Own study based on information from the Energy Regulatory Office.

The Polish law defines RES in the Act of 20 February 2015 on renewable energy sources (Ustawa $z$ dnia 20 lutego 2015 r...., 2020). The legal status of wind farms in Poland has been constantly changing over the past several years, thus affecting the tax obligations imposed on investors in the RES sector and contributing to revenues of communes where wind turbines are located. The tax obligation is specified in the Act of 1991 on taxes and local fees, which regulates the way real estate taxes are levied and collected. In the case of a wind farm, the taxation base is the value of the wind turbine, and the tax equals $2 \%$ thereof. The problem is that the value of the foundation and tower is relatively low in comparison with the technical equipment inside the tower and in the gondola. The value of these technical devices often surpasses $70 \%$ of the total value of a wind turbine (Czuba \& Wielec, 2019). Other sources suggest that the costs of construct- ing a tower correspond to about $26 \%$ of the total costs, of which $74 \%$ are the costs of the other components of a wind turbine (Paska \& Kłos, 2010).

Until 2016, there had been no legal definition in the Polish law of a wind turbine as a building object. The first definition appeared in the Act of 20 May 2016 on investments in wind farms (Ustawa $z$ dnia 20 maja 2016 r..., 2016). Article 2 of this act contains a legal definition of a wind farm, according to which a whole wind turbine including non-building components such as a gondola, turbine, etc. is defined as a building in the sense specified in the Building Law. Thus, the said act regulated the issue of building and seating wind farms in Poland (Wołowiec, 2018). This had tax implications in 2017.

As of 1 January 2017, a change was made with respect to the subject of the real estate tax (Czuba \& Wielec, 2019). As regards the taxation of wind farms from 1 
January to 31 December 2017, there were numerous disputes concerning the interpretation of the new law between taxpayers and the tax office. Was the tax base the building part of a wind turbine (the foundation and tower), or was it the entire wind turbine, including the power generating equipment? The matter was brought to the Supreme Administrative Court. In its judgement of 22 October 2018 (II FSK 2983/17) concerning the levying of real estate taxes on wind turbines, the Supreme Administrative Court shared the view of local governments, agreeing that the tax base should be the entire wind turbine and therefore dismissing the taxpayer's complaint. The Court ruled to levy a tax on the whole wind farm, which consists of at least the foundation, tower and technical equipment (Rudzka, 2019).

In the light of this judgement, it became obvious that 1 January 2017 marked a radical change in the real estate taxation of wind farms, as companies investing in wind farms were levied higher taxes, while local governments earned much higher revenues from taxes collected from wind farms located in their territory. This definition remained valid for slightly more than a year because the renewable energy producers as taxpayers lobbied effectively to amend the mentioned act. On 7 June 2018 an act amending the Act on RES was passed, which changed retroactively as of 1 January 2018 the definition of wind turbines and farms. According to the new definition, the building in a wind turbine is only its construction part, that is the foundations and the tower. Following the change in the definition of a wind turbine, relevant changes were made in the provisions of the Building Law (Ustawa $z$ dnia 7 czerwca 2018 r..., 2018). As a result, after the communes had approved their annual budgets, including higher revenues from wind farms similar to the ones obtained in 2017 , in mid-2018 they faced the consequences of the cited act, which retroactively decreased levels of real estate taxes levied on wind turbines. The legislator's practice was criticised in the aforementioned judgement of the Supreme Administrative Court, represented by 7 judges, which implicated certain flaws and their consequences regarding the retroactive effectiveness of the act (effective since January 2018) amending the act on renewable energy sources and some other acts (amendment of 7 June 2018), which also interfered with the Tax Law. The commune of Korsze, together with other communes associated in the union of communes and being in the same legal situation, brought an action against the State Treasury for compensation for the loss of real estate tax revenue in the first half of 2018.

The taxation of wind farms in Poland is a particularly complicated legal issue, and in the past several years there have been dramatic changes in both judicial practice and legislation. This is extremely disadvantageous for long-term planning by companies which would wish to invest in wind power generation and by communes, which are uncertain what real property tax revenues they will collect in subsequent financial years.

\section{The System of Wind Farms in the Korsze Commune}

Northern Poland, including the region of Warmia and Mazury, has an immense potential to develop power generation based on photovoltaic panels and wind turbines. The areas particularly predisposed to locate wind farms are found mostly in the central part of the province (Gadomska \& Antolak, 2014). An example is a small (with a population of slightly over 10,000), agricultural commune of Korsze, situated in the northern part of the Province of Warmia and Mazury.

In 2005, the Town Council of Korsze passed the Study of Conditions and Directions in the Spatial Management of the Commune and Town of Korsze. This document defined 'creating conditions favourable to the use of energy from the renewable sources available in the commune' as one of the commune's objectives, in addition to which it repeated the provision included in the plan for the whole province, concerning the localisation of wind farms in areas where they would not collide with the landscape protection and nature conservation (Raport o oddzialywaniu..., 2008).

After 2006, the authorities of the Korsze commune focused on the development of renewable energy generation in the commune's territory, aiming to maximise revenues (mainly from real property taxes) in order to satisfy various needs of the community. The construction of wind turbines 
was an enterprise which could take advantage of the local natural resources: very good wind conditions, the lowland relief, and a large distance from areas protected by Natura 2000, which could otherwise interfere considerably with the construction of wind farms (Wiśniewski et al., 2012).

On 14 April 2009, the Town Council in Korsze passed Resolution No XXXV/206/09 on the adoption of the local zoning plan for some of the territory of the Commune Korsze. This resolution permits the localisation of 60 wind power plants ${ }^{2}$ (referred therein as wind turbines) in the territory of the rural commune of Korsze.

After the resolution on the adoption of the local zoning plan became effective, a foreign investor was granted a building permit and subsequently began to assemble wind turbines, and to carry out construction work such as building access roads, wiring and fiberoptic installation and a transformer station in the village Olszynka. All this project was completed in less than a year, namely in October 2011. The final step was when the investor obtained a certificate of occupancy.

Thirty-five wind turbines were built, situated in 6 areas, in compliance with the local zoning plan. Each turbine has a nominal power of $2 \mathrm{MW}$, hence the total power of the Korsze wind farm is $70 \mathrm{MW}$. The turbines are $100 \mathrm{~m}$ high, the diameter of the rotors equals $90 \mathrm{~m}$, thus the maximum height including the rotor wings is $145 \mathrm{~m} .^{3}$

The resolutions passed by the Town Council of Korsze in 2015 made it possible to apply for a permit to expand the wind farm in Korsze. This provision became effective before a change in the localisation of wind farms was legalised (Act of 7 June 2018 on amending the act on renewable energy sources, 2018). In 2019, the foreign investor began to assemble fifteen new wind turbines with the total power generation capacity of $37 \mathrm{MW}$. The construction of these turbines is planned to be completed in mid-2020. The new wind turbines will be situated in the vicinity of the villages Gudziki, Płutniki and Chmielnik. ${ }^{4}$ This development will not have tax consequences until 2021.

\section{Methodology}

The main objective of this study was to assess the impact of wind farms on the eco- nomic and financial standing of the Korsze commune.

The study employed secondary data which were extracted from the sources of information provided by the departments of the Municipal Office in Korsze (for example, the report on the execution of the municipal budget, draft budgets, or resolutions on determination of real property tax rates), and supplemented with the data collected by Statistics Poland (GUS) and Energy Regulatory Office in 2010-2019.

The following sources of information had to be used:

1) Publicly available data on the website of the Public Information Bulletin of the Town Council in Korsze ${ }^{5}$, where, for example, the local government places annual reports on the execution of the planned budget of the given local government unit (Rb-27S),

2) Data acquired directly from the Municipal Office in Korsze, in compliance with the right to access to public information, and these included:

a) annual reports $\mathrm{Rb}-27 \mathrm{~S}$ from earlier time periods, unavailable on the PIB site;

b) printouts of the revenue part of the budgets of the Korsze commune, divided into sections, chapters and paragraphs, from the years 2011, 2015 and 2019;

c) statements of annual revenues earned by the Korsze commune from the real property taxes paid by companies which owned the wind farm, covering years 2012-2019.

The compilation and interpretation of the collected data consisted of their presentation in tables and description.

The research used the observational method and the method of examining documents.

\section{Analysis of the Revenues Earned by the Korsze Commune from Wind Turbines in 2012-2019}

The starting point for our analysis of the impact of wind turbines on the budget of the Korsze commune was the year 2011, which was the last year when the Korsze commune did not yet earn any proceeds from wind power plants. In the subsequent years, the tax on the real property occupied by wind turbines and associated infrastruc- 
ture was a regular feature in the Korsze commune's budget on the income side.

In 2011, the Korsze commune earned the revenue from the real property tax in the total amount of PLN 2982 044.00, of which PLN 2259696.00 (75.78\%) was paid by legal persons and PLN 722348.00 $(24.22 \%)$ by natural persons. During that time period, the wind farm's owners did not pay a tax yet (Figure 2).

Figure 2. Revenues of the Korsze commune from the real property tax in 2011-2019

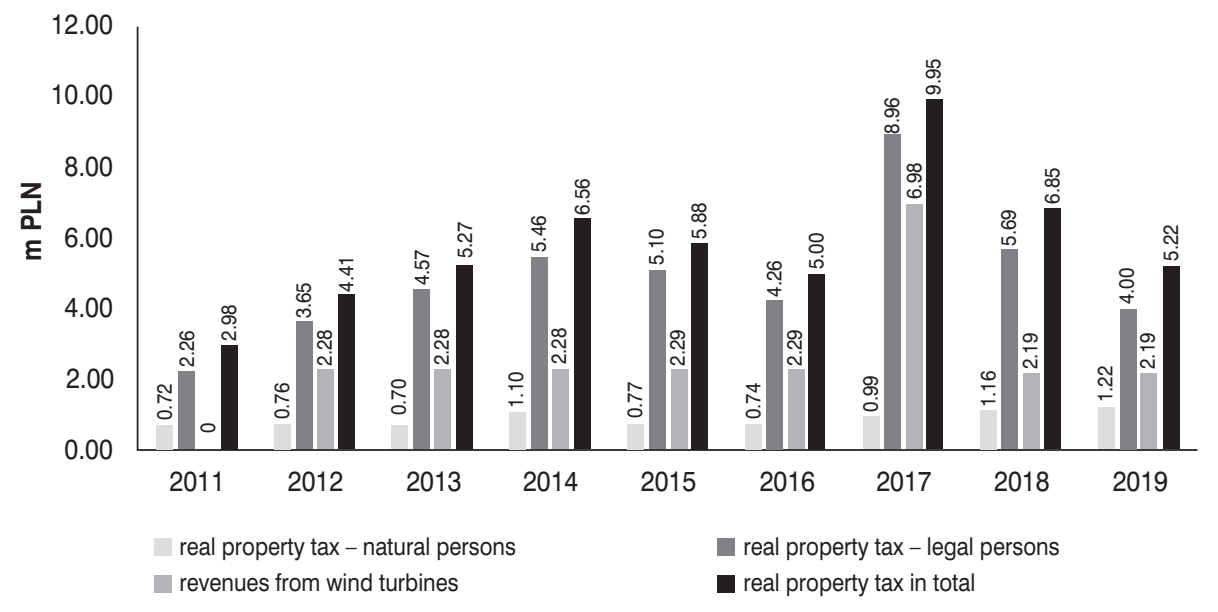

Source: The authors, based on reports Rb-27S and data from the Town Council in Korsze.

A large increase in the revenue from the real property tax was noted in the subsequent year. The income from this tax reached PLN 4411 951.98, i.e. by PLN 1429907.98 more than in 2011, which corresponds to a $48 \%$ increase. In the first budget year that included tax revenues from the wind farm, the Korsze commune collected directly from these wind turbines a real property tax in the amount of PLN 2275690 , which was $52 \%$ of the total real property tax revenues. Since that year, the sum of real property tax revenues earned by the Korsze commune has depended mostly on the taxes collected from the wind farm. The smallest contribution to the revenues from the real property taxes was made by natural persons, as the amount of these taxes remained relatively stable, ranging from PLN 700,000 to 1.2 million. The tax revenues from the wind farm in the same time period remained stable, too, reaching PLN 2.2-2.3 million a year, except the year 2017.

The year 2017 deserves special attention due to a rapid increase in revenues from real property taxes. In that year, the Korsze commune earned PLN 9.9 million from real estate taxes generally, of which
PLN 6.9 million were the taxes paid by the wind farm's owners. In 2017, relative to the preceding year, the Korsze commune doubled its revenue from real property taxes while the tax revenue from the wind turbines trebled. The reason for such a dramatic rise in the revenues was the change in levying taxes on wind turbines, mentioned earlier in this paper, which meant that the entire value of a wind turbine was taxed at a 2\% rate. The years 2018 and 2019 marked the return to the previous taxation rules regarding wind farms. The overall real property tax revenues of the Korsze commune decreased to PLN 6.8 million and PLN 5.2 million, respectively.

Since 2012, the tax revenue from the wind farm has been the most significant part of the income earned by the Korsze commune from real property taxation. In that year, the tax paid by the investors who owned the wind farm made up more than half of the total revenue of the Korsze commune obtained from real property taxation. The highest share of the revenue $(70 \%)$ from wind turbines in the total real property tax revenues was noted in 2017. In the other budget years analysed, this percentage varied between 32 and 51\%. What this 
means is that the Korsze commune's revenues from real property taxes to a large extent depend on the legal regulations con- cerning the levying of taxes on wind power plants (Table 1).

Table 1. Contribution of revenues from the wind turbines to the real property tax revenues in total

\begin{tabular}{|c|c|c|c|}
\hline Year & Share [\%] & $\begin{array}{c}\text { Revenues from wind turbines } \\
\text { [PLN] }\end{array}$ & $\begin{array}{c}\text { Real property tax in total } \\
\text { [PLN] }\end{array}$ \\
\hline 2011 & 0.00 & 0.00 & 2982044.00 \\
\hline 2012 & 51.58 & 2275690.00 & 4411951.98 \\
\hline 2013 & 43.35 & 2282927.00 & 5265812.28 \\
\hline 2014 & 34.80 & 2282927.00 & 6561044.00 \\
\hline 2015 & 38.99 & 2290821.00 & 5876038.00 \\
\hline 2016 & 45.80 & 2288419.00 & 4996198.00 \\
\hline 2017 & 70.18 & 6981961.00 & 9948020.00 \\
\hline 2018 & 32.03 & 2193366.00 & 6847645.13 \\
\hline 2019 & 42.02 & 2193531.00 & 5219628.00 \\
\hline
\end{tabular}

Source: The authors, based on reports published by the Town Council in Korsze.

Our further analysis dealt with changes in the structure of the Korsze commune's revenues. Three budget years were analysed, that is 2011, as a year with no tax revenue from wind farms, 2015, when the commune earned a tax from a wind farm, being also a year before the social support programme $500+$ was started, and 2019, which is the last budget year available, and a time period when the budget of the Korsze commune obtained revenues from wind turbines as well as target grants to implement the $500+$ programme.

While analysing the revenues of the Korsze commune, one notices that a relatively largest income consists of the state grants allocated to the performance of the tasks delegated by the state for communes to carry out, including social welfare programmes. Thus, in 2011, the Korsze com- mune was granted by the state an amount of over PLN 11 million, in 2015 the total state grants reached 15 million, and in 2019, due to the $500+$ programme, the amount of state grants was nearly PLN 20 million, which corresponded to $42 \%$ of all the revenues of the commune in that year.

State subsidies are another significant item among the revenues of the Korsze commune, chiefly the education subsidy, which reached PLN 7.5 million in 2011 and in 2015, and nearly PLN 8 million in 2019. Other revenues in those years equalled PLN 2.5 million in 2011, PLN 7 million in 2015 and PLN 3 million in 2019. Among tax revenues, the most important were derived from real property tax, agricultural tax and the share of the personal income tax allocated to the commune (Table 2). 
Table 2. Structure of revenues of the Korsze commune in years 2011, 2015 and 2019

\begin{tabular}{|l|r|r|r|r|r|r|}
\hline \multirow{2}{*}{ Sources of revenues } & \multicolumn{2}{|c|}{$\mathbf{2 0 1 1}$} & \multicolumn{2}{c|}{$\mathbf{2 0 1 5}$} & \multicolumn{2}{c|}{$\mathbf{2 0 1 9}$} \\
\cline { 2 - 8 } & $\begin{array}{c}\text { amount } \\
\text { [PLN] }\end{array}$ & $\begin{array}{c}\text { share } \\
\text { [\%] }\end{array}$ & $\begin{array}{c}\text { amount } \\
\text { [PLN] }\end{array}$ & $\begin{array}{c}\text { share } \\
{[\%]}\end{array}$ & $\begin{array}{c}\text { amount } \\
\text { [PLN] }\end{array}$ & $\begin{array}{c}\text { share } \\
{[\%]}\end{array}$ \\
\hline Grants & 11555522.49 & 33.92 & 14715444.16 & 32.77 & 19855066.27 & 42.51 \\
\hline Others & 2595152.64 & 7.62 & 7158614.59 & 15.94 & 3093901.83 & 6.62 \\
\hline Real property tax & 2982044.00 & 8.75 & 5876038.00 & 13.09 & 5219628.00 & 11.18 \\
\hline Agricultural tax & 2291381.00 & 6.73 & 3712494.00 & 8.27 & 2665947.00 & 5.71 \\
\hline Forest tax & 64600.00 & 0.19 & 76240.00 & 0.17 & 108893.00 & 0.23 \\
\hline Tax on vehicles & 82817.00 & 0.24 & 77340.00 & 0.17 & 41730.00 & 0.09 \\
\hline $\begin{array}{l}\text { Inheritance } \\
\text { and donation tax }\end{array}$ & 20000.00 & 0.06 & 45000.00 & 0.10 & 30000.00 & 0.06 \\
\hline Fees for keeping dogs & 32500.00 & 0.10 & 16255.00 & 0.04 & 20448.00 & 0.04 \\
\hline Street market fees & 21000.00 & 0.06 & 10300.00 & 0.02 & 5000.00 & 0.01 \\
\hline $\begin{array}{l}\text { Tax on civil law } \\
\text { transactions }\end{array}$ & 102000.00 & 0.30 & 120000.00 & 0.27 & 297000.00 & 0.64 \\
\hline $\begin{array}{l}\text { Fees for off-licence } \\
\text { permits }\end{array}$ & 96850.00 & 0.28 & 106783.00 & 0.24 & 127616.00 & 0.27 \\
\hline Personal income tax & 2446636.00 & 7.18 & 3375964.00 & 7.52 & 4650973.00 & 9.96 \\
\hline Corporate income tax & 20000.00 & 0.06 & 220000.00 & 0.49 & 199575.15 & 0.43 \\
\hline $\begin{array}{l}\text { State subsidy } \\
\text { for education }\end{array}$ & 7591961.00 & 22.28 & 7525248.00 & 16.76 & 7936684.00 & 16.99 \\
\hline Equalising subsidy & 3932166.00 & 11.54 & 1678523.00 & 3.74 & 2042334.00 & 4.37 \\
\hline Balancing subsidy & 0.00 & 0.00 & 191762.00 & 0.43 & 138967.00 & 0.30 \\
\hline Supplementary subsidy & 234206.00 & 0.69 & 0.00 & 0.00 & 269321.00 & 0.58 \\
\hline TOTAL: & 34068836.13 & 100.00 & 44906005.75 & 100.00 & 46703084.25 & 100.00 \\
\hline
\end{tabular}

Source: The authors, based on reports published by the Town Council in Korsze.

The data set out in the table show that the revenue from agricultural tax in the Korsze commune remained on a relatively stable level of PLN 2 to 3 million a year. Relative to the year 2011, there was a dramatic rise in the commune's revenue from real property taxes in the subsequent years, which was mostly because of the taxes paid by the wind farm's owners. Between 2011 and 2019, there was also a noticeable increase in the revenue from personal income tax. This may have been owing to the unemployment rate decreasing and the country's economic situation improving over that period of time.

An analysis of the percentage structure of the budget of the Korsze commune shows that the largest income items are grants $(33.92 \%)$, and subsidies, including the subsidy for education $(22.28 \%)$ and supplementary subsidy (11.54\%). Property tax generated $8.75 \%$ of the commune's budget, personal income tax $-7.18 \%$, agricultural tax $-6.73 \%$, other incomes $-7.62 \%$ and other fees and taxes $-1.29 \%$.

In 2015, the structure of the revenues earned by the Korsze commune included the tax revenue from the wind farms, which did not feature in the 2011 budget. The contribution of real property tax revenue rose from $8.75 \%$ in to $13.09 \%$. The amount of state grants in the budget remained almost unchanged, while the other incomes increased from 7.62 to $15.94 \%$. The per cent contribution of agricultural and personal income tax revenues did not change significantly over these four years. Compared to the 2011 budget, there was 
a considerable rise in the amount of revenues from PLN 34 to 44.9 million, which is a $31.81 \%$ increase. Another significant change was an increase in revenues from property taxes, both in terms of their sum and percentage in the total revenues. The key reason why the per cent share of real property tax revenues in the commune's total income increased was the taxes levied on wind turbines. The commune's income not only increased but also became more diversified.

More changes in the structure of the revenues of the Korsze commune occurred in 2019. The most evident change was the increase in the contribution of state grants in the commune's income, which rose from $32.77 \%$ to $42.51 \%$. The cause was the implementation of the $500+$ programme. In 2019, the Korsze commune received a target grant in the amount of PLN 7.2 million for child benefits under this programme and another grant in the amount of PLN 5.3 million for family benefits.

The year 2019 was the second tax year after the regulation to tax only the value of the building components of a wind turbine (the foundations and the tower) had become applicable again. The real property tax revenues decreased slightly relative to the year 2015, from PLN 5.9 million to PLN 5.2 million, with their percentage in the total revenues declining to $11.18 \%$. The personal income tax revenues increased over the 4 years, both in absolute figures and in their per cent share, owing to the economic boom. Meanwhile, the agricultural tax revenue decreased slightly (down to $5.71 \%$ of the total revenue).

In 2015-2019, the total value of the commune's revenues increased only slightly, by about PLN 1.7 million. The second stage of the expansion of the wind farm will not have its consequences for the Korsze commune's revenues until the year 2021 as long as the wind turbines under construction now are connected to the power grid and obtain a certificate of occupancy. The structure of revenues earned by the commune of Korsze in 2019 was strongly influenced by social welfare programmes carried out by the state, but in this case the commune acts as 'a cashier' who pays the funds received from the state to final beneficiaries.

\section{Summary and Conclusions}

The importance of wind energy in the world and also in Poland has been continuously growing for several decades. In 2015, wind farms supplied the global population $3.5 \%$ of the world's demand for electric power. In 2019, the capacity of installed wind farms in Poland amounted to 5.92 GW ( $64.98 \%$ of the total RES capacity), which meant an increase of $401 \%$ compared to 2010.

The renewable energy development in recent years has undoubtedly influenced the socio-economic development in Poland, maintaining the principles of sustainable development, not only in terms of environmental protection, but also in the context of economic benefits in this respect. Acquiring RES investors by local and regional authorities could contribute to local and regional development, and consequently to the development of the entire country.

The search for funds by local authorities, their collection and, above all, their effective use is undoubtedly an important task of each local development process. It is very important to rationally, skilfully and effectively use the local potential and all kinds of diverse resources at the disposal of individual communes.

The case of the Korsze commune, discussed in this paper, proves that the construction of a large wind farm can greatly contribute to increasing revenues earned by a municipality from the real property tax. The annual income from this tax in the first year when the wind farm began to operate doubled. In the subsequent years, the property taxes paid by the wind farm's owners constituted between $30 \%$ up to $70 \%$ of the total revenues of the commune. As a result, the commune's income increased significantly and the commune authorities could allocate more funds to local development (e.g. modernisation of: technical infrastructure, water supply and sewage networks, roads, fiber optic network, as well as investing in social infrastructure: building schools, clinics, construction and renovation of apartments, etc.), which has a direct impact on the increase in the quality of life of the local community. 


\section{Endnotes}

1 Energy Regulatory Office, https://www.ure.gov. $\mathrm{pl} / \mathrm{pl} /$ oze/potencjal-krajowy-oze/5753,Moc-zainstalowana-MW.html, access: 16.12.2020.

2 Although the local zoning plan envisaged possible construction of 60 wind turbines in the commune, only 35 localisations of wind turbines were actually used.

3 EDP Renewables, https://www.edpr.com/ poland/sites/edprpoland/files/edpr_2011_korsze_eia-streszczenie-nietechnicne_pl-1.pdf, access: 11.04.2020.

4 Korsze Municipal Website, https://korsze. pl/PL/1000/365/ROZBUDOWA FARMY WIATROWEJ_W_KORSZACH/k/, access: 11.04.2020.

5 Public Information Bulletin Town Hall in Korsze, https://bip.korsze.pl/, access: 11.04.2020.

\section{References}

Apergis, N., \& Payne, J.E. (2010). Renewable energy consumption and economic growth: Evidence from a panel of OECD countries. Energy Policy, 38, 656-660.

BP. (2016). Statistical world energy review 2016, (52).

Carvalho, M.G.S. (2012). EU energy and climate change strategy. Energy, 40(1), 19-22. DOI: 10.1016/j.energy.2012.01.012.

Copena, D., Perez-Neira, D., \& Simon, X. (2019). Local economic impact of wind energy development: Analysis of the regulatory framework, taxation, and income for Galician communes. Sustainability, 11(2403), 1-18.

Czuba, M., \& Wielec, M. (2019). Opodatkowanie elektrowni wiatrowych w Polsce - wybrane aspekty. internetowy Kwartalnik Antymonopolowy i Regulacyjny (iKAR), 5, 6-7.

Gadomska, W., \& Antolak, M. (2014). Wybrane aspekty planistyczne lokalizacji elektrowni wiatrowych w województwie warmińsko-mazurskim. Architektura Krajobrazu, (1), 106.

Gozgor, G. (2016). Are shocks to renewable energy consumption permanent or transitory? An empirical investigation for Brazil, China, and India. Renewable and Sustainable Energy Reviews, 66, 913-919.

Hilpert, S., Dettner, F., \& Al-Salaymeh, A. (2020). Analysis of cost-optimal renewable energy expansion for the near-term Jordanian electricity system. Sustainability, 12(22), 9339. https://doi.org/10.3390/ su12229339.

Igliński, B., Iglińska, A., Koziński, G., Skrzatek, M., \& Buczkowski, R. (2016). Wind energy in Poland - History, current state, surveys, Renewable Energy
Sources Act, SWOT analysis. Renewable and Sustainable Energy Reviews, 64, 19-33.

Jabłońska, M., \& Zieliński, J. (2011). Rozwój odnawialnych źródeł energii na poziomie gminy. Śląskie Wiadomości Elektryczne, 97, 23.

Kim, Y.J., \& Wilson, Ch. (2019). Analysing future change in the EU's energy innovation system. Energy Strategy Reviews, 24, 279-283. DOI:https:// doi.org/10.1016/j.esr.2019.04.012.

Marks-Bielska, R., \& Bielski, S. (2013). Wzrost roli rolnictwa w zapewnieniu bezpieczeństwa energetycznego kraju. Wieś i Rolnictwo, (4), 149-160.

Marks-Bielska, R., \& Bielski, S. (2018). Bezpieczeństwo żywnościowe i energetyczne w kontekście produkcji biokomponentów płynnych. Przedsiębiorczość i Zarzadzanie, XIX(4), Part I, 145-159. Wyd. SAN.

Marks-Bielska, R., Bielski, S., Novikova, A., \& Romaneckas, K. (2019). Straw stocks as a source of renewable energy. A case study of a district in Poland. Sustainability, 11, 4714. https://doi. org/10.3390/su11174714.

Marks-Bielska, R., Bielski, S., Pik, K., \& Kurowska, K. (2020). The importance of renewable energy sources in Poland's energy mix. Energies, 13(4624), 1-23.

Menyah, K., \& Wolde-Rufael, Y. (2010). $\mathrm{CO}_{2}$ emissions, nuclear energy, renewable energy and economic growth in the US. Energy Policy, 38, 2911-2915.

Ministerstwo Rozwoju. (2017). Strategia na rzecz odpowiedzialnego rozwoju do roku 2020 (z perspektywa do 2030 r.). Warszawa.

Munday, M., Bristow, G., \& Cowell, R. (2011). Wind farms in rural areas: How far do community benefits from wind farms represent a local economic development opportunity?. J. Rural Stud., 27, 1-12.

Nolden, C. (2013). Governing community energyFeed-in tariffs and the development of community wind energy schemes in the United Kingdom and Germany. Energy Policy, 63, 543-552.

Paska, J., \& Kłos, M. (2010). Elektrownie wiatrowe w systemie elektroenergetycznym - przyłączanie, wpływ na system i ekonomika. Rynek Energii, 1, 7.

Payne, J.E. (2010). Survey of the international evidence on the causal relationship between energy consumption and growth. Journal of Economic Studies, 37(1), 53-95. DOI: http://dx.doi. org/10.1108/01443581011012261.

Przedsiębiorstwo Gospodarki Gruntami w Olsztynie. (2008). Raport o oddziatywaniu na środowisko sporzadzony przez TOPOZ Przedsiębiorstwo Gospodarki Gruntami w Olsztynie. Olsztyn. 
Rada Miejska w Korszach. (2009). Uchwała Nr XXXV/206/09 Rady Miejskiej w Korszach z dnia 14 kwietnia 2009 r. w sprawie uchwalenia miejscowego planu zagospodarowania przestrzennego części terenów Gminy Korsze. Korsze.

Rada Miejska w Korszach. (2015a). Uchwata Nr VI/16/2015 Rady Miejskiej w Korszach $z$ dnia 20 lutego 2015 r. w sprawie uchwalenia miejscowego planu zagospodarowania przestrzennego części terenów gminy Korsze $w$ obrębie geodezyjnym Błogoszewo, Kraskowo, Ptutniki. Korsze.

Rada Miejska w Korszach. (2015b). Uchwata Nr X/44/2015 Rady Miejskiej w Korszach z dnia 12 czerwca $2015 \mathrm{r}$. w sprawie uchwalenia miejscowego planu zagospodarowania przestrzennego części terenów gminy Korsze - miejscowości Tolkiny, Ptutniki, Starynia, Chmielnik, Gudziki, Dzikowina i Podgórzyn. Korsze.

Rudzka, J. (2019). Opodatkowanie wiatraków podatkiem od nieruchomości. Finanse Publiczne, 1.
Ustawa z dnia 20 lutego 2015 r. o odnawialnych źródtach energii (Dz. U z 2020 r., poz. 261, 284).

Ustawa z dnia 20 maja 2016 r. o inwestycjach w zakresie elektrowni wiatrowych (Dz. U. z 2016 r. poz. 961).

Ustawa z dnia 7 czerwca 2018 r. o zmianie ustawy o odnawialnych źródtach energii oraz niektórych innych ustaw (Dz.U. z 2018 r., poz. 1276).

Wiśniewski, G., Michałowska-Knap, K., \& Koć, S. (2012). Energetyka wiatrowa stan aktualny i perspektywy rozwoju w Polsce. Warszawa: Instytut Energetyki Odnawialnej.

Wołowiec, T. (2018). Studium przypadku: opodatkowanie farmy wiatrowej (elektrowni wiatrowych) podatkiem od nieruchomości. International Journal of Legal Studies (IJOLS), 2, 204.

Żygadło, M., \& Madejski, R. (2016). The conversion of biomass into energy in farm biogas plant. Archives of Waste Management and Environmental Protection, 18(2), 55-66. 